\title{
Pemantau pilihan raya zombie di dalam pilihan raya umum Malaysia
}

\author{
Norazam Mohd Noor, Muhamad Takiyuddin Ismail, Muhamad Nadzri Mohamed Noor \\ Program Sains Politik, Pusat Kajian Sejarah, Politik dan Hal Ehwal Antarabangsa, \\ Fakulti Sains Sosial dan Kemanusiaan, Universiti Kebangsaan Malaysia \\ Correspondence: Norazam Mohd Noor (email: azamnoor88@gmail.com)
}

Received: 03 March 2020; Accepted: 14 April 2020; Published: 30 May 2020

\begin{abstract}
Abstrak
Konotasi bersih dan adil adalah ideal sesebuah pilihan raya yang demokratik. Ia antara lain, menggarisbawahi sejauh mana legitimasi sesebuah kerajaan yang dipilih melalui pilihan raya. Selain dari parti politik, organisasi-organisasi pemantauan pilihan raya memainkan peranan penting dalam memerhati, mengukur dan menilai perjalanan sesebuah pilihan raya. Namun, kajian terhadap organisasi-organisasi ini sangat kurang mendapat tempat. Kebanyakan tulisan ilmiah yang menyentuh organisasi-organisasi ini bersifat kurang terfokus dan hanya melibatkan pemerihalan sampingan, khasnya di dalam korpus ilmu sains politik di Malaysia. Artikel ini, untuk itu, secara amnya diasaskan untuk menganalisis sifat, fungsi dan operasi organisasi-organisasi pemantauan pilihan raya domestik di Malaysia. Manakala, secara khusus, artikel ini cuba membangkitkan kes kewujudan pemantau pilihan raya zombie di dalam Pilihan Raya Umum 2013 dan 2018. Berdasarkan kajian ke atas tiga organisasi pemantauan zombie di dalam kedua-dua pilihan raya itu, artikel ini menghujahkan organisasi pemantauan zombie telah di rekayasa secara kreatif oleh parti pemerintah untuk mengabsahkan pilihan raya, sekali gus memberi legitimasi kepada pemerintah meskipun terdapat pelbagai manipulasi autoritarian di dalam pilihan raya itu. Hal ini adalah sesuatu yang tidak dapat dielakkan bagi sesebuah negara yang mempunyai sistem politik hibrid yang tinggi, di mana pilihan raya masih perlu dilakukan bagi memperbaharui legitimasi pemerintahan. Kebanyakan hujahan dan analisis di dalam artikel diperoleh melalui temu bual dengan aktor-aktor penting, pemerhatian langsung dan kajian kepustakaan.
\end{abstract}

Kata Kunci: organisasi pemantauan pilihan raya domestik (DEMOs), pemantau pilihan raya zombie, Suruhanjaya Pilihan Raya, Pilihan Raya Umum Malaysia 2013, Pilihan Raya Umum Malaysia 2018, masyarakat sivil

\section{Zombie election monitors in the Malaysia general elections}

\begin{abstract}
Free and fair are the ideals of a democratic election. These ideals underscore the idea on how much an elected government can be construed as a legitimate ruling body. Election
\end{abstract}


monitoring organisations, apart from political parties, have played significant roles in observing, measuring and assessing electoral procedures and processes. Nevertheless, academic research on these organisations often overlooked and thus very limited. Most of the electoral studies frequently reflected the organisations in a passing mention, rather than providing a focused and detailed examination, particularly in the Malaysian political science corpus. This article, therefore, intends to fill this lacuna by providing an analysis over the nature, functions and operation of domestic election monitoring organisations in Malaysia. More specifically, this article explores the existence of zombie electoral monitor organisations in the 2013 and the 2018 General Elections. Based on the studies of three selected electoral watch organisations, this article argues that zombie electoral monitors were cunningly engineered by the then ruling party to invoke the idea of lawfulness in its electoral process, and thus providing legitimacy to the government although there were many discrepancies and authoritarian manipulation along the process. This was rather inevitable to a state of hybrid political system, such as Malaysia, whereby elections are still needed to renew legitimacy to its political elites. Most of the arguments made in this article are based on a qualitative research, namely by doing interviews with the relevant actors, direct observations and library studies.

Keywords: domestic election monitoring organisations (DEMOs), zombie election monitors, Election Commission, $13^{\text {th }}$ General Election of Malaysia, $14^{\text {th }}$ General Election of Malaysia, civil society

\section{Pengenalan}

Kekalahan kerajaan Barisan Nasional (BN) semasa Pilihan Raya Umum (PRU) 2018 merupakan suatu keputusan di luar jangkaan ramai. Peralihan tampuk kepimpinan kepada Pakatan Harapan (PH) daripada pemerintahan kerajaan BN selama 61 tahun membuktikan keefektifan sistem pilihan raya Malaysia sebagai representasi kehendak rakyat, meskipun praktisnya sering kali terpalit dengan persepsi kecondongannya terhadap pemerintah. Sejajar dengan sifat pilihan raya Malaysia yang bebas tetapi tidak adil (Saravanamuttu, 2016), kerajaan BN menggunakan beberapa kelebihannya sebagai penyandang kuasa seperti gerrymandering dan malapportionment (Wong Chin Huat, 2018), penganugerahan projekprojek pembangunan semasa tempoh kempen pilihan raya dan juga perbelanjaan tanpa batasan calon-calonnya (Weiss, 2016; Ufen, 2013) serta kawalan media yang menyeluruh (Mustafa, 2005).

Desakan terhadap pematuhan prinsip-prinsip demokrasi mendorong kepada penglibatan pihak ketiga yang tidak berkepentingan iaitu organisasi pemantau pilihan raya domestik (DEMOs). PRU 1990 merupakan julung kalinya urusan pemantauan bebas dijalankan oleh Election Watch (EW). Lanjutan daripada agenda "Reformasi", inisiatif Pemantau Pilihan Raya Rakyat Malaysia 1999 (PEMANTAU 1999) digerakkan oleh gabungan sejumlah lebih daripada 40 buah badan bukan kerajaan (NGO) tempatan pada PRU 1999. Perubahan dasar Suruhanjaya Pilihan Raya (SPR) membolehkan Malaysians for Free and Fair Election (MAFREL) diberikan akreditasi pada April 2007 sebagai pemerhati rasmi PRU 2008 (MAFREL, 2017). Meskipun ruang penyertaan kepada organisasi yang berorientasikan anti-kerajaan seperti ini tidak kekal lama di atas isu kepatuhan prosedur, namun ia memperlihatkan wujudnya kesedaran di pihak SPR untuk bekerjasama dengan organisasi yang mempunyai kecenderungan yang berbeza. Penerusan konsep pemerhati rasmi ini pada PRU 2013 dan 2018 turut membuka jalan penyertaan pelbagai NGO dan organisasi masyarakat sivil (CSO). Campur tangan politik di dalam aktiviti pemantauan telah membuka 
ruang penyertaan yang banyak oleh organisasi yang pro kepada pemerintahan BN seperti badan bukan kerajaan yang ditubuhkan oleh kerajaan (GONGO) serta NGO yang ditubuhkan semata-mata bagi tujuan pemantauan PRU 2018. Manakala, organisasi yang dianggap antikerajaan seperti Pemantau Pilihan Raya Rakyat (PEMANTAU) 2013 dan 2018 yang ditunjangi oleh Gabungan Pilihan Raya Bersih dan Adil (BERSIH) disekat penyertaan mereka. Artikel ini dengan itu cuba memerihalkan penglibatan apa yang dianggap sebagai kumpulan pemantau pilihan raya zombie di dalam PRU 2013 dan PRU 2018. Kupasan perbincangan meneliti sifat dan fungsi pemantau zombie, dan pengaruhnya terhadap pengoperasian dan peranan pemantauan mereka. Dengan melihat beberapa NGO yang dapat dikategorikan sebagai pemantau pilihan raya zombie, ia menghujahkan bahawa organisasi pemantau zombie di Malaysia di rekayasa secara kreatif oleh parti pemerintah untuk mengabsahkan sistem pilihan raya di Malaysia, berbanding sebagai badan penyemak yang sebenar. Ia bertujuan untuk memberi keabsahan kepada pemerintah meskipun manipulasi autoritarian diguna pakai di dalam sistem pilihan raya itu. Hal ini adalah sesuatu yang tidak dapat dielakkan bagi sesebuah negara yang mempunyai sistem politik hibrid yang tinggi, di mana pilihan raya masih perlu dilakukan bagi memperbaharui keabsahan pemerintahan. Penegasan juga perlu dibuat bahawa kehadiran pemantau zombie bukanlah sebagai penyebab utama mengenai keputusan PRU 2013 dan PRU 2018. Artikel ini hanya ingin meneliti bagaimana ia dioperasikan bagi memberikan keabsahan tambahan kepada sistem pilihan raya yang terdedah kepada beberapa manipulasi utama. Artikel ini juga tidak memberi maksud bahawa badan pemantau lain seperti MAFREL dan PEMANTAU merupakan contoh kepada pemantau bebas dan neutral kerana pertubuhan-pertubuhan ini juga mempunyai agenda politik yang jelas dan berada dekat dengan gabungan Pakatan Rakyat (PR)/PH.

Artikel ini diharap dapat memperbanyakkan kajian mengenai DEMOs di Malaysia yang terabai dalam korpus kajian pilihan raya dan pendemokrasian. Sehingga kini, banyak kajian mengenai DEMOs terarah kepada penyentuhan mengenai DEMOs yang bersifat antikerajaan seperti Funston (2000), Ying (2014) dan Chan (2018). Muhamad Takiyuddin dan Norazam (2020) pula memfokuskan mengenai peranan pemantau pilihan raya akademik dalam PRU 2018 serta pemantau pilihan raya antarabangsa di Malaysia (2020b). Walaupun penyentuhan mengenai pemantau zombie ada dinyatakan dalam kedua-dua artikel mereka, ia hanya diperihalkan sepintas lalu dan tanpa dilatari oleh perbincangan yang lebih analitis.

\section{Konsep pemantauan pilihan raya}

Pemantauan pilihan raya ditakrifkan sebagai suatu penugasan oleh sekumpulan individu yang diberikan autoriti untuk memerhati dan membuat intervensi terhadap sesuatu proses pilihan raya, sekiranya terdapatnya sebarang ketidakpatuhan terhadap undang-undang dan prosedur pilihan raya itu (International Institute for Democracy and Electoral Assistance (International IDEA), 1997). Pemantauan dibahagikan kepada tiga kategori utama, iaitu pemantauan domestik, pemantauan antarabangsa dan penyelia antarabangsa. Aktiviti pemantauan domestik dilaksanakan oleh pelbagai organisasi nasional, terutamanya daripada kumpulan sosial dan NGO yang tidak partisan. Manakala, misi kerajaan, organisasi pelbagai hala, dan NGO antarabangsa merupakan antara organisasi yang menjalankan aktiviti pemantauan antarabangsa. Penyelia antarabangsa pula terdiri daripada organisasi antara kerajaan (IGO) yang menjalankan penilaian terhadap sesuatu pelaksanaan proses pilihan raya pasca konflik (Bjornlund, 2004). Secara terminologi, sememangnya wujud perbezaan takrifan antara "pemantau" (yang bersifat jangka panjang iaitu selama tujuh minggu) dan juga "pemerhati" (hanya terlibat secara singkat semasa tempoh rasmi pilihan raya iaitu penamaan calon hinggalah pengumuman keputusan pilihan raya) (Bjornlund, 2004; Organization for 
Security and Cooperation in Europe (OSCE), 2010; Election Observation and Democratic Support (EODS), 2016). Begitu pun, sarjana dan aktivis tempatan yang ditemu bual cenderung tidak mengaplikasikan kedua-dua takrifan ini secara ketat. Justeru, bagi tujuan keseragaman, kami hanya menggunakan istilah pemantau dalam artikel ini.

Kewujudan DEMOs menjadi perhatian selepas kejayaan National Citizens' Movement for Free Elections (NAMFREL) dalam membantu menumbangkan pemerintahan Ferdinand Marcos di Filipina pada 1986 (Hedman, 2006). Kejayaan NAMFREL telah mencetuskan inspirasi kepada penubuhan DEMOs di kebanyakan negara khususnya di negara autoritarian dan semi-autoritarian. Antara DEMOs aktif adalah seperti Citizens Organized to Monitor Elections (GONG), International Society for Fair Elections and Democracy (ISFED), Media Monitoring (MEMO 98), Center for Free Elections and Democracy (CeSID), Fair Election Monitoring Alliance (FEMA), NAMFREL, Electoral Assistance Bureau (EAB) dan Transparencia. Bersesuaian dengan perubahan demokrasi, urusan pemantauan turut mengalami perkembangan pesat. Pewujudan The Global Network of Domestic Election Monitors (GNDEM) pada 2009 berupaya menaungi sejumlah 175 buah organisasi daripada 70 buah negara terutamanya di Afrika, Amerika Latin dan Asia (Norris, 2017). Penginstitusian aktiviti pemantauan oleh kebanyakan negara, meletakkannya di suatu tahap tertentu di dalam sistem pilihan raya. NAMFREL umpamanya, merupakan contoh antara DEMOs yang mendapat status khas daripada Commission on Elections Philippines (COMELEC) bagi menjalankan urusan pemantauan domestik. Pengiktirafan sebegini turut melatari ke atas pelbagai DEMOs di Georgia, yang memperoleh ruang untuk mengemukakan bantahan rasmi terhadap pengesanan salah laku di dalam pilihan raya (Lopez-Pintor, 2004). Kajian oleh Max Grompingpada 2017 pula menemukan terdapatnya tiga faktor yang memacu pertumbuhan pesat DEMOs dalam urusan pemantauan. Pertama, melalui pengaruh antarabangsa seperti sokongan pendanaan dan penyebaran norma daripada badan-badan antarabangsa. Kedua, tahap keyakinan awam yang tinggi terhadap peranan DEMOs sebagai ejen yang menggerakkan modal sosial. Ketiga, kewujudan struktur peluang selaras dengan rungutan awam terhadap ketelusan pilihan raya (Gromping, 2017). Walau bagaimanapun, kemajuan urusan pemantauan global ini tidak dirasai dalam konteks pilihan raya Malaysia. Meskipun aktiviti ini telah bermula sejak PRU 1990 hingga terkini pada PRU 2018, namun sehingga kini ia masih lagi tidak diinstitusikan sewajarnya. Justeru, peranannya untuk menambah baik pelaksanaan proses pilihan raya masih lagi belum kelihatan jelas. Salah satu aspek yang menyumbang kepada perkara ini ialah kewujudan pemantau pilihan raya zombie.

\section{Kedudukan pemantauan pilihan raya zombie}

Penyertaan DEMOs dapat dikelompokkan kepada dua kumpulan, iaitu kumpulan pemerhati profesional (POG) dan kumpulan pemerhati bayangan (SOG). Aktiviti pemantauan POG dilakukan secara bebas serta telus, dan sering kali memberi manfaat kepada kemajuan sistem pilihan raya. Penglibatan partisan SOG mencetuskan kepada pelaporan yang mengesahkan pengurusan pilihan raya, yang selalunya digunakan oleh kerajaan sebagai pilihan kedua bagi menyembunyikan segala manipulasi yang dilakukan (Debre \& Morgenbesser, 2017).

Sememangnya, aspek pemantauan berupaya memberi impak kepada ketelusan sesuatu pilihan raya. Pertamanya, kewujudan sekatan sosial yang mengekang tindak-tanduk segala pihak yang berisiko terlibat dalam penipuan pilihan raya seperti ejen-ejen calon, petugaspetugas pilihan raya dan perayu undi. Keduanya, kehadiran DEMOs secara tidak langsung turut meningkatkan penyertaan pihak berautoriti dalam menguatkuasakan segala bentuk tindakan undang-undang (Asunka et al., 2014). Kerjasama erat antara DEMOs dengan organisasi pemantau pilihan raya antarabangsa (IEMOs) turut memberikan manfaat kepada 
kedua-dua pihak. Kehadiran IEMOs menawarkan kaedah pelaporan yang memenuhi norma antarabangsa, dan pada masa yang sama penglibatan DEMOs memudahkan aktiviti di lapangan seperti agihan aktivis di pusat-pusat mengundi, kelancaran komunikasi, serta pemahaman yang lebih jelas mengenai budaya dan konteks politik (Bjornlund, 2004).

Aspek positif seperti ini turut dikenal pasti oleh beberapa kajian lain. Berdasarkan penelitian terhadap pelaksanaan pilihan raya di Azerbaijan, Zimbabwe dan Venezuela, penyertaan DEMOs yang diyakini berupaya untuk meningkatkan keabsahan pilihan raya (Merloe, 2015). Kajian oleh Michael Cecire menemukan pengaruh DEMOs terhadap keputusan pilihan raya Georgia 2012. Penyertaan aktif DEMOs seperti Georgian Young Lawyers Association dan Transparency International-Georgia berupaya mengurangkan manipulasi dan menjadi pemangkin kepada peralihan kerajaan melalui kemenangan parti Georgian Dream di dalam pilihan raya itu (Cecire, 2013). Kehadiran DEMOs dapat meredakan sebarang bentuk keganasan pilihan raya, yang begitu banyak terjadi di dalam pelaksanaan pilihan raya di negara-negara Afrika. Sewaktu pilihan raya Nigeria 2015, kehadiran DEMOs bertindak sebagai faktor penyederhana yang mengurangkan ketegangan dan risiko keganasan sebelum pilihan raya (Tunde, MohdAzizuddin \& Ummu Atiyah, 2016). Hal yang sama turut dialami sewaktu pilihan raya Ghana 2012. Melalui kutipan data kuantitatif ke atas personel daripada Coalition of Domestic Election Observers (CODEO), wakil badan pengendali pilihan raya dan wakil parti-parti politik di 1,000 saluran pengundian, dapatan kajian ini turut mengesahkan sumbangan DEMOs dalam mengekalkan keharmonian pilihan raya (Asunka et al., 2017). Justeru, kerajaan autoritarian seringkali mengambil beberapa tindakan dalam menyekat kehadiran dan penglibatan DEMOs. Halangan yang dikenakan pemerintah adalah seperti membataskan fungsi dan peranan DEMOs di dalam urusan pemantauan (Chigudu, 2015), beradaptasi dengan kehadiran DEMOs dengan melakukan manipulasi strategik (Sjoberg, 2012), dan menjemput IEMOs yang rendah kualiti bagi melegitimasikan sesuatu pilihan raya (Kelley, 2012). Turut menjadi kaedah penting ialah menggunakan pemantau zombie atau adakalanya turut digelar sebagai phony (Walker, 2016; Bush \& Prather, 2017).

Pengkajian terdahulu mencirikan pemantau zombie ini sebagai sebuah organisasi di bawah kawalan kerajaan yang berfungsi sebagai DEMOs dalam pilihan raya. Bersesuaian dengan gelarannya, DEMOs zombie berperanan untuk menyediakan laporan pemantauan yang menyokong terhadap implementasi peraturan dan prosedur pilihan raya di bawah pemerintahan sesebuah kerajaan, meskipun secara nyatanya ia dihimpit oleh pelbagai salah laku dan manipulasi (Merloe, 2015). Potensi pelaporan memihak yang ditawarkan oleh DEMOs berkategori zombie ini merupakan antara sebab utama yang mendorong kerajaan untuk lebih menggunakan khidmatnya sebagai DEMOs, berbanding dengan organisasi pemantauan antarabangsa di dalam pelaksanaan pilihan raya (Cooley, 2015). Justeru, pemantau zombie dilihat hanya tertumpu pada pengekalan kepentingan elit, dan tidak mengimpak perubahan sosial (Callahan, 2000). Hal ini kerana ia hanya dimanipulasikan kerajaan bagi tujuan menjalankan aktiviti pemantauan secara partisan (Bush \& Prather, 2018).

DEMOs zombie merupakan pilihan terbaik kerajaan dalam urusan pemantauan pilihan raya kerana, kebanyakan kerajaan begitu meragui pengaruh yang dibawa oleh DEMOs dan IEMOs terhadap keyakinan awam ke atas kualiti pelaksanaan pilihan raya, dan pada masa yang sama berhadapan dengan desakan pematuhan terhadap norma antarabangsa. Kecenderungan politik DEMOs zombie yang mempunyai pertautan dengan kerajaan merupakan faktor penarik penglibatan mereka di dalam aktiviti pemantauan. Kecondongan orientasi politik ini merupakan asas utama pemilihan kerajaan autoritarian ke atas DEMOs bagi menjalankan pemantauan pilihan raya. Malah, dorongan ini turut mengetepikan aspekaspek utama seperti kepakaran, kompetensi dan kredibiliti pemantauan sesebuah DEMOs 
(Cooley, 2015). Tidak seperti IEMOs yang mempunyai reputasi dan kredibiliti baik dalam urusan ini, pelaporan lunak DEMOs zombie berkaitan dapatan pemantauan mereka terhadap pelaksanaan pilihan raya oleh sesebuah kerajaan mengundang kritikan pelbagai pihak. Hal ini disebabkan oleh persepsi awam yang tidak meyakini keneutralan DEMOs zombie ini dalam menjalankan aktiviti pemantauan mereka (Lynge-Mangueira, 2012). Salah satu contoh DEMOs zombie adalah seperti Commonwealth of Independent States (CIS). Meskipun mengaplikasikan teknik pemantauan yang mematuhi piawaian antarabangsa, dapatan pemantauan CIS semasa pilihan raya Ukraine 2010 yang mengesahkan ketelusan pilihan raya itu adalah bercanggah dengan dapatan pemantauan majoriti organisasi lain yang terlibat (Cooley, 2015).

Dapatan kajian lepas turut menggambarkan pelbagai sisi dapatan pemantauan oleh DEMOs zombie. Kehadiran Movement for Defence of Voters' Rights (GOLOS) semasa pilihan raya di Duma, Russia pada 2011 tidak memberi kesan terhadap jumlah undi diterima United Russia, selaku pemerintah di wilayah itu. Hal ini kerana, DEMOs zombie ini gagal mengesan sebarang bentuk penipuan dan manipulasi pilihan raya yang dilakukan oleh kerajaan bagi meningkatkan sokongan undi mereka (Buzin, Brondum \& Robertson, 2016; Skovoroda \& Lankina, 2017). GOLOS juga cenderung untuk melantik "pakar pemantauan" yang diragui kompetensinya, contohnya seperti Mateusz Piskorski dan Bartosz Kownacki daripada Poland yang juga merupakan penyokong kuat kepada kerajaan Russia. Justeru, tidak hairanlah laporan pemantauan yang disediakan bersifat lebih lunak dan menyokong kualiti pelaksanaan pilihan raya. Kenyataan-kenyataan seperti "there were no violations", "elections in Russia and the West are organized similarly" dan "the special trait of the elections is the use of state-of-the-art digital technologies for counting and processing the votes" merupakan antara frasa utama yang sering kali digunakan dalam pelaporan pemantauan GOLOS (European Platform for Democracy Election (EPDE), 2017).

Situasi seperti ini turut berlaku bagi pelaksanaan pilihan raya di negara-negara Timur Tengah. Benstead, Kao dan Lust (2015) mentadbirkan dua alat ujian iaitu Governance Local Development (GLD) ke atas seramai 1,499 orang responden semasa pilihan raya Jordan 2014, dan Local Governance Performance Index (LGPI) ke atas seramai 3,659 orang responden semasa pilihan raya Tunisia 2015. Kajian ini merumuskan kehadiran dan pelaporan pemantauan DEMOs tidak langsung mempengaruhi keputusan rakyat dalam pemilihan kerajaan. Strategi manipulasi pemerintah dalam pemantauan turut melibatkan dapatan secara kolektif daripada pelbagai DEMOs zombie. Semasa pilihan raya presiden Azerbaijan 2013, terdapat 42 buah DEMOs dijemput bagi memantau pelaksanaan pilihan raya itu. Sebilangan besar DEMOs ini tidak diketahui umum, malah reputasinya juga turut diragui. Kekurangan kritikan oleh DEMOs zombie ini terhadap pelaksanaan pilihan raya merupakan faktor sokongan yang mengekalkan pemerintahan Presiden Ilham Aliyev bagi penggal ketiga (Cooley, 2015).

Imej negatif yang dibawa oleh DEMOs zombie mengurangkan keyakinan pihak antarabangsa terhadap penglibatan DEMOs di dalam aktiviti pemantauan secara total. Justeru, pelaporan yang disediakan kurang mempunyai pemberat dan autoriti berbanding dengan kualiti pelaporan DEMOs serantau (Norris, 2017). Ia juga merupakan antara sebab yang menghalang penglibatan promoter antarabangsa untuk menyokong aktiviti pemantauan DEMOs (Carothers, 1997). Sehubungan itu, sebanyak dua cabaran DEMOs turut digariskan, iaitu menghapuskan tohmahan terhadap kecenderungan politik dan meningkatkan keyakinan terhadap kualiti pemantauan (Geisler, 1993). 


\section{Metodologi kajian}

Kajian kualitatif ini mengguna pakai kaedah kajian kes yang menggabungkan penganalisisan data daripada sumber sekunder dan temu bual tidak berstruktur. Informan merupakan aktoraktor pilihan raya yang terdiri daripada kepimpinan tertinggi SPR, serta pelbagai organisasi domestik dan antarabangsa yang terlibat secara rasmi dan bebas di dalam aktiviti pemantauan. Malah, pengalaman libat serta ketiga-tiga penulis di dalam aktiviti pemantauan semasa PRU 2018 turut memberi pandang dalam yang berguna dalam kajian ini.

\section{Kajian kes Majlis Belia Malaysia, Majlis Belia Sabah dan Persatuan Pengundi Wawasan Malaysia Kuala Lumpur}

Sejak kali pertama aktiviti pemantauan pilihan raya dijalankan pada PRU 1990, penyertaan DEMOs bebas dan rasmi berhubungan secara berlawanan antara satu sama lain. Bilangan DEMOs bebas yang bermula sejak PRU 1990 seolah-olah kurang mendapat sambutan, dan hanya mencatatkan peningkatan secara mendadak pada PRU 2008, dan kemudiannya semakin berkurangan pada tahun-tahun pilihan raya berikutnya. Manakala, penyertaan DEMOs rasmi pula yang bermula sejak PRU 2008 mula berkembang dan mendapat tempat dalam sistem politik Malaysia, terutamanya semasa PRU 2013 dan 2018. Statistik penyertaan kedua-dua kategori DEMOs ini adalah seperti di Jadual 1.

Fenomena ini adalah selaras dengan hala tuju kepimpinan SPR itu sendiri, yang kurang membuka ruang penglibatan IEMOs tetapi pada masa yang sama sangat mengalualukan penyertaan DEMOs di dalam aktiviti pilihan raya Malaysia (Wan Ahmad Wan Omar, 2018: temu bual).

Jadual 1. Penyertaan DEMOs bebas dan rasmi bagi PRU 1990-2018

\begin{tabular}{cccc}
\hline \multirow{2}{*}{ PRU } & \multicolumn{2}{c}{ Bil. Penyertaan DEMOs } & \multirow{2}{*}{ Jumlah } \\
\cline { 2 - 3 } & Bebas & Rasmi & 1 \\
1990 & 1 & - & - \\
1995 & - & - & 2 \\
1999 & 2 & - & 1 \\
2004 & 1 & - & 11 \\
2008 & $10^{*}$ & 1 & 20 \\
2013 & 3 & 17 & 15 \\
2018 & 1 & 14 & $\mathbf{5 0}$ \\
Jumlah & $\mathbf{1 8}$ & $\mathbf{3 2}$ & \\
\hline
\end{tabular}

* Termasuk penyertaan pemantauan Pilihan Raya Negeri (PRN) Sarawak 2011, serta Pilihan Raya Kecil (PRK) pasca PRU 2008 dan PRN Sarawak 2011

Sumber: Diubahsuai daripada Loh, 2010; Malaysian Voters’ Union (MALVU), 2009; Muhamad Takiyuddin, 2019; My MAFREL, 2011; Ong Boon Keong, 2019: temu bual; PEMANTAU (2014, 2018); SPR (2013, 2018); UCA News, 1990

Pegangan prinsip ini sememangnya membuka ruang penyertaan pemantauan rasmi yang seluas-luasnya kepada begitu banyak NGO dan GONGO tempatan. Begitu pun, majoriti NGO dan GONGO yang menyertai aktiviti pemantauan ini berlatar belakangkan etnik dan kumpulan sosial, serta beroperasi di Sabah dan Sarawak. Antara DEMOs rasmi aktif adalah seperti Majlis Belia Malaysia (MBM), Majlis Belia Sabah (MBS) dan Persatuan Pengundi Wawasan Malaysia Kuala Lumpur (PPWMKL). Namun, penyertaan NGO dan GONGO ini terpalit dengan pandangan negatif dan pelbagai kritikan yang meragui aktiviti pemantauan partisan mereka. 
MBM merupakan sebuah GONGO yang bertindak sebagai penyelaras dalam menubuhkan, membimbing, menggalakkan dan kerjasama dengan persatuan-persatuan belia di seluruh negara. Fungsi MBM adalah termaktub seperti mana yang digariskan dalam Akta Pertubuhan Belia dan Pembangunan Belia 2007 yang merupakan salah satu elemen penting di bawah seliaan Kementerian Belia dan Sukan (KBS). GONGO ini bertanggungjawab untuk menggalakkan kemajuan belia yang seimbang dari aspek ekonomi, sosial, mental, fizikal, akhlak dan politik. Di samping itu, MBM juga menjalankan pelbagai aktiviti dalam membentuk jati diri anak bangsa dan menyemai semangat cintakan negara (MBM, 2020). MBS pula merupakan salah satu organisasi gabungan MBM yang berfokuskan kepada pembangunan belia di Sabah. Bermula sebagai Sabah National Youth Association (SANYA), organisasi ini dijenamakan semula kepada MBS pada 1994. MBS bertindak sebagai organisasi induk yang memantau prestasi 17 buah organisasi belia gabungannya daripada bahagian-bahagian di Sabah (Azuwan, 2018: temu bual). Bersesuaian dengan peranannya, MBM begitu aktif dalam memberi pandangan terhadap perkembangan politik Malaysia. Antaranya seperti penglibatan lebih ramai belia sebagai calon-calon parti dalam pilihan raya (Adib Povera, 2019), dan usaha SPR menurunkan had umur pengundi kepada 18 tahun (Bernama, 2019). Meskipun prinsip asas pemilihan kepimpinan MBM dan MBS adalah berdasarkan pencalonan daripada persatuan-persatuan gabungannya (prinsip ini dibuktikan melalui pelantikan mantan Naib Presiden Angkatan Belia Islam Malaysia (ABIM) Jufitri Joha sebagai Presiden MBM, dan Timbalan Yang Di-Pertua ABIM Sabah Ahmad Farid Sainuri sebagai Presiden MBS), namun ia masih dibelenggu dengan pengaruh politik. Contohnya, pelantikan Lajim Ukim (ahli politik yang pernah menyertai United Malays National Organisation (UMNO) dan Parti Keadilan Rakyat (PKR) sebagai presiden pertama MBS (Azuwan, 2018: temu bual). Penglibatan PPWMKL di dalam urusan pemantauan pula menimbulkan keraguan. Meskipun NGO ini melepasi piawaian prosedur pelantikan oleh SPR, namun tinjauan lapangan merumuskan PPWMKL ditubuhkan semata-mata bertujuan untuk memerhati perjalanan PRU 2018 sahaja (Muhamad Takiyuddin \& Muhamad Nadzri, 2018).

Pengkategorian DEMOs zombie bagi MBM, MBS dan PPWMKL ini adalah berdasarkan pertimbangan ke atas aspek-aspek dominan dan sokongan yang mempengaruhi urusan pemantauan mereka. Dari segi aspek dominan, afiliasi politik ketiga-tiga DEMOs ini merupakan faktor utama yang mempengaruhi bias aktivis dalam menjalankan tugasan lapangan. Seperti mana penjelasan sebelum ini, berlakunya "campur tangan" politik dalam barisan kepimpinan MBM dan MBS, serta penubuhan PPWMKL. Masalah seperti ini turut berlaku di negara serantau Indonesia, yang mana pemerintahan Soeharto mewujudkan DEMOs zombie Tim Objektif Pemantau Pemilu (TOPP) sebagai usaha melemahkan kredibiliti pemantauan Komite Independen Pemantau Pemilu (KIPP) (Virgianita, 2014). Situasi ini turut memberi kesan terhadap pemilihan aktivis lapangan bagi menjalankan tugasan pemantauan, yang mana di dominasi oleh para penyokong parti $\mathrm{BN}$ yang turut serta berkempen untuk parti itu di dalam pilihan raya (Muhamad Nadzri, 2018; Muhamad Takiyuddin \& Muhamad Nadzri, 2018; Yap Swee Seng, 2019: temu bual). Hinggakan, kecondongan MBM yang berkempen untuk calon BN semasa PRU 2018 di kerusi Dewan Undangan Negeri (DUN) Galas, Kelantan turut dikesan, direkodkan dan dimuatkan dalam laporan pemantauan DEMOs lain (PEMANTAU 2018). Kompetensi aktivis lapangan MBM, MBS dan PPWMKL juga turut mendapat pertikaian. Meskipun ketiga-tiga DEMOs ini berupaya menggerakkan begitu ramai aktivis pemantauannya di lapangan, kualiti yang dipamerkan oleh mereka tidak mencapai tahap yang memuaskan seperti mana prestasi DEMOs lain yang lebih profesional. Pelantikan aktivis pemantauan di lapangan seolah-olah dibuat secara "tangkap muat" di saat akhir. Kes pemantauan di Bentong, Pahang dan Kuala Terengganu, Terengganu menemukan kebanyakan aktivis lapangan MBM tidak mempunyai 
tahap pendidikan tinggi, tidak bekerja dan tidak jelas dengan peranan mereka (Muhamad Nadzri, 2018). Masalah yang sama turut dirasai oleh MBS, yang mengakui kebanyakan ahli mereka tidak mempunyai sebarang pengalaman sebagai petugas pilihan raya (Azuwan, 2018: temu bual).

Sokongan kewangan yang kukuh merupakan satu lagi indikasi yang mewajarkan taraf zombie ketiga-tiga pertubuhan. Meskipun kami tidak menemui sebarang bukti sahih bagi mengesahkan MBM, MBS dan PPWMKL menerima sebarang dana daripada kerajaan BN dalam menjalankan urusan pemantauannya, bilangan anggota pemantau mereka yang jauh lebih ramai daripada beberapa badan pemantau lain menyarankan bahawa ketiga-tiga mereka didanai secara substantif (lihat Jadual 2).

Jadual 2. Penglibatan aktivis Pemerhati MBM, MBS dan PPWMKL bagi PRU 2013-2018

\begin{tabular}{cccc}
\hline \multirow{2}{*}{ Nama DEMOs } & \multicolumn{2}{c}{ Bilangan Penyertaan Aktivis Pemerhati } & \multirow{2}{*}{ Jumlah } \\
\cline { 2 - 3 } & PRU 2013 & PRU 2018 & \\
\hline MBM & 412 & 391 & 803 \\
MBS & 53 & 35 & 88 \\
PPWMKL & - & 641 & 641 \\
Jumlah & $\mathbf{4 6 5}$ & $\mathbf{1 , 0 6 7}$ & $\mathbf{1 , 5 3 2}$ \\
\hline
\end{tabular}

Sumber: SPR $(2013,2019)$

MBM merupakan antara DEMOs yang proaktif dalam menyediakan dana bagi membiayai aktiviti pemantauan di lapangan. Perbualan dengan seorang pemerhati MBM di Parlimen Kuala Kangsar dalam PRU 2018 mendapati bahawa mereka akan dibayar bayaran lump-sum sebanyak RM1,000 untuk setiap laporan akhir yang dikemukakan selepas tamatnya pilihan raya. Berdasarkan pengalaman MBS, DEMOs ini berupaya menyediakan elaun kepada aktivis pemantauannya berjumlah RM480 bagi penugasan selama 16 hari sewaktu PRU 2013. Namun, kekangan kewangan menjejaskan kantung mereka dan hanya mampu menyediakan elaun berjumlah RM240 bagi penugasan 12 hari pada PRU 2018 (Abqaree Fawwaz, 2018: temu bual; Azuwan, 2018: temu bual). Pendanaan kerajaan ke atas DEMOs zombie merupakan trend yang berlaku di beberapa negara serantau. Antaranya seperti kes PollWatch di Thailand dan beberapa CSO di Indonesia (Callahan, 2000; Ichal Supriadi, 2019: temu bual). Walaupun pendanaan kerajaan ke atas DEMOs mengikis keyakinan umum terhadap kualiti pemantauan yang dijalankannya, tindakan ini dipertahankan oleh Pengerusi Jawatankuasa Khas Pembaikan Sistem dan Undang-Undang Pilihan Raya (ERC) Abdul Rashid Abdul Rahman kerana “...kerajaan [perlu sediakan] duit, tapi DEMOs ini mesti melalui sedikit ujian, [perlu patuh pada] kriteria tertentu...”. Penyaluran bantuan ini juga diperlukan sebagai suatu usaha untuk mengupayakan pemantauan DEMOs, dan menghalang kemasukan IEMOs yang diragui hasratnya kerana "...[IEMOs] ini mempunyai agenda tersendiri [apabila menjalankan pemantauan]..." (2019: temu bual).

Perbezaan ketara antara DEMOs zombie berbanding DEMOs profesional lain dapat diperhatikan melalui kualiti pelaporan yang disediakan. Biarpun kelemahan yang sama turut dikesan dalam kebanyakan DEMOs yang bertugas dalam PRU 2013 dan PRU 2018, MBM dan PPWMKL wajar diberi lebih tumpuan berikutan status mereka yang menghantar jumlah pemantau terbesar. Bersesuaian dengan statusnya, PPWMKL tidak langsung menghebahkan sebarang bentuk laporannya. Hanya MBM sahaja yang mengambil inisiatif untuk mengetengahkan inti pati laporan pemantauan mereka kepada pengetahuan umum (Astro Awani, 2013). Pelaporan MBM dan MBS berupaya meneliti aspek-aspek pematuhan prosedur pilihan raya di sepanjang tempoh rasmi pilihan raya serta merekodkan perlanggaran peraturan oleh pelbagai aktor berkaitan, namun ia tidak disediakan secara tersusun dan jelas. Fokus pelaporan hanya tertumpu kepada penyenaraian masalah dan cadangan penyelesaian 
sahaja (MBM, 2013; MBS, 2013). Hal ini begitu berbeza dengan laporan pemantauan sistematik dan komprehensif yang disediakan oleh dua DEMOs profesional yang bertugas dalam PRU 2013 seperti Institute for Democracy and Economic Affairs (IDEAS) dan Merdeka Center (lihat IDEAS, 2013; Merdeka Center, 2013).

Status zombie ketiga-tiga pertubuhan lebih dapat diperjelaskan apabila kesemua pertubuhan ini tidak lagi terlibat dalam sepuluh siri pilihan raya kecil yang diadakan selepas PRU 2018. Begitu pun, pengecualian adalah pada MBM yang hanya menyertai PRK Rantau dan Sandakan pada 2019 dengan melibatkan penugasan aktivis secara total seramai lima orang sahaja.

\section{Kesimpulan}

Berdasarkan kajian ke atas tiga organisasi pemantau di dalam artikel ini, wujud bukti untuk mencadangkan bahawa badan-badan itu telah di rekayasa secara kreatif oleh BN ketika itu untuk mengabsahkan pilihan raya. Organisasi-organisasi pemantau zombie ini adalah sebahagian daripada mekanisme tambahan bagi mengabsahkan keputusan pilihan raya dalam sistem semi-autoritarian seperti di Malaysia. Oleh kerana itu, terdapat pelbagai kemusykilan dan kekurangan badan pemantau seumpama ini yang bertentangan dengan prinsip sebenar sesebuah organisasi pemantau pilihan raya yang bebas dan neutral. Pemantau pilihan raya zombie tidak diasaskan untuk memenangkan parti pemerintah, contohnya seperti menambah undi atau menyelewengkan pengiraan sebagaimana tuduhan yang pernah dilemparkan kepada pentadbiran BN dahulu. Sebaliknya sifatnya adalah untuk meningkatkan ilusi ketelusan sesuatu pilihan raya walaupun secara simbolik. Dengan penyertaan anggota yang begitu ramai seperti mana yang dilihat dalam kes PPWMKL dan MBM, ia berupaya memberi gambaran bahawa pengawasan secara menyeluruh dan telus telah dilakukan oleh pemerintah. Namun dari sudut fungsi dan operasinya, organisasi pemantau zombie, sebagaimana yang telah dihujahkan di dalam artikel ini adalah untuk mengabsahkan perjalanan pilihan raya secara kosmetik. Hal ini juga dapat menjelaskan mengapa pemilihan DEMOs di Malaysia di bawah pentadbiran $\mathrm{BN}$ adalah sangat terkawal dan sesetengahnya melibatkan individuindividu yang meragukan termasuk wakil dari parti pemerintah dan organisasi yang berkait dengannya. Jarang sekali organisasi-organisasi ini, memberi pelaporan kepada SPR, apatah lagi kepada umum tentang dapatan mereka dalam pilihan raya yang telah dipantau mereka, sekali gus memperlihatkan kewujudan mereka lebih sebagai ilusi berbanding badan pemantau yang sebenar. Hal ini dengan itu menjurus kepada pelbagai kelemahan daripada sudut sumber manusia yang diguna pakai, sumber kewangan, identiti organisasi dan gerak kerja sebenar organisasi-organisasi itu. Sebagai mana yang telah dibincangkan, badan pemantau yang lebih bebas juga dipilih secara selektif oleh agensi kerajaan BN termasuk IDEAS dan daripada universiti-universiti tempatan. Namun, jumlahnya adalah kecil dan tidak meluas berbanding jumlah organisasi pemantau zombie.

Di bawah pentadbiran PH dari Mei 2018 ke Februari 2020 yang menyaksikan berlangsungnya sepuluh siri PRK, organisasi pemantau zombie masih muncul tetapi dalam bentuk yang lebih halus (subtle). Kebanyakan mereka mempunyai hubungan dekat dengan parti-parti gabungan PH. Hal ini berlaku berikutan penyerapan aktivis-aktivis pro-PH dan BERSIH dalam kepimpinan SPR yang baharu. Situasi ini membuka jalan kepada organisasi pemantau yang sebelumnya tidak diberi akses sebagai pemantau rasmi untuk bertindak sebagai citizens arms kepada SPR seperti BERSIH, Tindak Malaysia dan Engage. Biarpun kumpulan-kumpulan ini tidak boleh dianggap secara simplistik sebagai pemantau zombie kerana keupayaan dan kompetensi mereka secara relatif, ia membuka jalan kepada kritikan bias dan berada dekat dengan kerajaan PH. Sebagai contoh, BERSIH dikritik oleh golongan 
pro-demokrasi sendiri kerana bersikap lunak dalam mengkritik salah laku pilihan raya yang dilakukan PH semasa PRK Tanjung Piai (Free Malaysia Today, 2019). Kes yang agak lebih jelas boleh diteliti daripada penyertaan badan-badan pemantau yang berafiliasi dengan parti politik tertentu seperti Universiti Selangor (UNISEL), Institut Darul Ehsan (IDE) dan juga Akademi Pendidikan Demokrasi dan Kewarganegaraan (APDK) (berafiliasi dengan PKR) serta Malaysia Corruption Watch (MCW) dan Milenium Malaysia (berafiliasi dengan BERSATU). Fenomena ini sekali lagi menjelaskan bahawa kewujudan pemantau zombie tidak terhad berlaku dalam era BN tetapi juga PH. Ia menyarankan pemilihan organisasi pemantau pilihan raya yang secara relatifnya bebas dan berkecuali masih menjadi cabaran penting dalam memajukan sistem pemantauan pilihan raya di Malaysia.

\section{Penghargaan}

Kesemua penulis merakamkan ucapan terima kasih kepada Universiti Kebangsaan Malaysia (UKM) di atas pendanaan kajian ini melalui geran GUP 2018-161, rakan strategik SPR yang membekalkan data dan informasi yang diperlukan, serta para informan yang meluangkan masa untuk ditemu bual.

\section{Rujukan}

Abdul Rashid Abdul Rahman, Pengerusi ERC, Putrajaya. (2019, 14 Januari). Temu bual.

Abqaree Fawwaz Abekan, Timbalan Presiden MBS, Kota Kinabalu. (2018, 18 Disember). Temu bual.

Adib Povera. (2019). Parties urged to field more young candidates in next GE. New Straits Times, 17 Julai. Diperoleh daripada https://www.nst.com.my/news/nation/2019/07/ 505171/parties-urged-field-more-young-candidates-next-ge.

Astro Awani. (2013). MBM: PRU13 tepati prosedur, undang-undang. 29 Mei. Diperoleh daripada http://www.astroawani.com/berita-malaysia/mbm-pru13-tepati-prosedurundang-undang-15204.

Asunka, J., Brierly, S., Golden, M., Kramon E., \& Ofosu, G. (2014). Protecting the polls: The effect of observers on election fraud. Los Angeles, University of California.

Asunka, J., Brierley, S., Golden, M., Kramon, E., \& Ofosu, G. (2017). Electoral fraud or violence: The effect of observers on party manipulation strategies. British Journal of Political Science, 1(1), 1-23.

Azuwan Marjan@ Norjan, Mantan Timbalan Presiden MBS, Kota Kinabalu. (2018, 18 Disember). Temu bual.

Benstead, L., Kao, K., \& Lust, E. (2015, 9-10 April). Why does it matter what observers say? The impact of international monitoring on the electoral legitimacy. The second annual conference of the Governance and Local Development (GLD) center. Yale University, New Haven.

Bernama. (2019). MBM supports amendments to lower voting age. 17 Julai. Diperoleh daripada http://www.bernama.com/en/news.php?id=1747515.

Bjornlund, E.C. (2004). Beyond free and fair: Monitoring elections and building democracy.Baltimore, The John Hopkins University Press.

Bush, S.S., \& Prather, L. (2017). The promise and limits of election observers in building election credibility. The Journal of Politics, 79(3), 921-935.

Bush, S.S., \& Prather, L. (2018). Who's there? Election observer identity and the local credibility of elections. International Organization, 72(1), 659-692. 
Buzin, A., Brondum, K., \& Robertson, G. (2016). Election observer effects: A field experiment in the Russian Duma election of 2011. Electoral Studies 44 (1), 184-191.

Callahan, W. (2000). Pollwatching, elections and civil society in Southeast Asia. Singapore, Ashgate.

Carothers, T. (1997). The observers observed. Journal of Democracy 8 (3), 17-31.

Cecire, M. (2013). Georgia's 2012 elections and lessons for democracy promotion. Orbis, $57(2), 232-250$.

Chan, Tsu Chong. (2018). Democratic breakthrough in Malaysia - Political opportunities and the role of Bersih. Journal of Current Southeast Asian Affairs, 37(3), 109-137.

Chigudu, D. (2015). Foreign election observers in Africa: Towards an obligations-based approach. Mediterranean Journal of Social Sciences, 6(1 S1), 272-278.

Cooley, A. (2015). Countering democratic norms. Journal of Democracy 26 (3), 49-63.

Debre, M. J., \&Morgenbesser, L. (2017). Out of the shadows: Autocratic regimes, election observation and legitimation. Contemporary Politics, 23(3), 328-347.

EODS. (2016). Handbook for European Union election observation. (Edisi ke-3). Luxembourg, Publication Office of the European Union.

EPDE. (2017). "Electoral tourist" from abroad: Who are they? 10 September. Diperoleh daripada https://www.epde.org/en/documents/category/observe-the-observer-16.html.

Free Malaysia Today. (2019). Blatant bribery in Tanjung Piai, says rights activist. 13 November.

Diperoleh

https://www.freemalaysiatoday.com/category/nation/2019/11/13/ tanjung-piai-says-rights-activist/.

Funston, J. (2000). Malaysia's tenth elections: Status quo, reformasi or Islamization. Contemporary Southeast Asia, 22(1), 23-59.

Geisler, G. (1993). Fair? What has fairness got to do with it? Vagaries of elections observations and democratic standards. The Journal of Modern African Studies, 31(4), 613-637.

Gromping, M. (2017). Domestic monitors.Dlm. Norris, P. \&Nai, A. (pnyt.). Election watchdogs: Transparency, accountability and integrity (ms. 167-190). New York: Oxford University Press.

Hedman, E.E. (2006). In the name of civil society: From free election movements to people power in the Philippines. Honolulu, University of Hawaii Press.

IchalSupriadi, Ketua Setiausaha Asia Democracy Network (ADN), Bangkok. (2019, 11 Februari). Temu bual.

IDEAS. (2013). Was GE13 free and fair? An interim observation report on Malaysia's 13th General Election. Kuala Lumpur, IDEAS and CPPS.

International IDEA. (1997). Code of conduct. Ethical and professional observation of elections. Stockholm, International IDEA Publication.

Kelley, J.G. (2012). Monitoring democracy: When international election observation works, and why it often fails. Princeton, Princeton University Press.

Loh, D. (2010). Watching our elections. The Nut Graph. 26 Mei. Diperoleh daripada http://www.thenutgraph.com/ watching-our-elections/.

Lopez-Pintor, R. (2004). Concluding remarks and lessons learned. Dlm. O'Grady, P., LopezPintor, R. \& Stevens, M. (pnyt.). Promoting and defending democracy: The work of domestic election observer groups around the world (ms. 113-114). London: NEEDS.

Lynge-Mangueira, H. (2012). Why 'professionalizing' international election observation might not be enough to ensure effective election observation. Stockholm, International IDEA Publication.

MAFREL. (2017). Home \& about. Diperoleh daripada https://mafrel.wordpress.com. 
MALVU. (2009). No street names despite modern housing in Bukit Selambau. Diperoleh daripada http://malvu.blogspot.com.

MBM. (2013). Laporan pemerhati tempatan pilihan raya umum ke-13. Laporan yang tidak diterbitkan.

MBM. (2020). Siapa kami. Diperoleh daripada http://belia.org.my/wp/siapa-kami/.

MBS. (2013). Laporan pemerhati tempatan pilihan raya umum kali ke-13. Laporan yang tidak diterbitkan. 1-48.

Merdeka Center. (2013). GE13: Election watch report. Bangi, Merdeka Center.

Merloe, P. (2015). Election monitoring vs. disinformation. Journal of Democracy, 26(3), 7993.

Muhamad Nadzri Mohamed Noor. (2018). The 14th General Election, the fall of Barisan Nasional, and political development in Malaysia, 1957-2018. Journal of Current Southeast Asian Affairs, 37(3), 139-171.

Muhamad Takiyuddin Ismail. (2019). Bantuan demokrasi di Malaysia: Melewati pertukaran rejim. Kuala Lumpur, Penerbit Universiti Malaya.

Muhamad Takiyuddin Ismail \& Muhamad Nadzri Mohamed Noor. (2018). Revolusi senyap 9 Mei 2018. Jebat: Malaysian Journal of History, Politics and Strategic Studies, 45(2), 161-185.

Muhamad Takiyuddin Ismail \& Norazam Mohd Noor. (2020). Pemerhati pilihan raya domestik di Malaysia: Kajian kes ahli akademik sebagai pemerhati pilihan raya. Kajian Malaysia (forthcoming).

Muhamad Takiyuddin Ismail \& Norazam Mohd Noor. (2020b). Resisting international election observation through election visit programme: The case of Malaysia. Journal of Current Southeast Asian Affairs (forthcoming).

Mustafa K. Anuar. (2005). Politics and the media in Malaysia. Kasarinlan: Philippine Journal of Third World Studies, 20(1), 25-47.

My MAFREL. (2011). New group mobilising observers for clean election. Diperoleh daripada http://mymafrel.blogspot.com/2011/12/new-group-mobilising-observersfor.html.

Norris, P. (2017). Strengthening electoral integrity. New York, Cambridge University Press.

Ong Boon Keong, Pengasas Malaysia Election Observation Network (MEO-Net) dan mantan koordinator MAFREL Wilayah Utara, Kuala Lumpur. (2019, 8 Februari). Temu bual.

OSCE. (2010). Election observation handbook. (Edisi ke-6). Warsaw, OSCE Office for Democratic Institutions and Human Rights.

PEMANTAU. (2014). Clean \& fair: An election observation report for GE13. Petaling Jaya, EMPOWER.

PEMANTAU. (2018). Election observation report of the 14th Malaysian General Elections. Petaling Jaya, Bersih \& Adil Network Sdn Bhd.

Saravanamuttu, J. (2016). Power sharing in a divided nation: Mediated communalism and new politics in six decades of Malaysia's elections. Singapore, ISEAS Publishing.

Sjoberg, F. M. (2012). Making voters count: Evidence from field experiments about the efficacy of domestic election observation. Seminar Harriman Institute, Kertas Kerja no. 1. Columbia University, New York.

Skovoroda, R., \&Lankina, T. (2017). Fabricating votes for Putin: New tests of fraud and electoral manipulations from Russia. Post-Soviet Affairs, 33(2), 100-123.

SPR. (2013). Laporan Pilihan Raya Umum ke-13. Putrajaya, SPR.

SPR. (2018). Surat SPR kepada pengkaji. 30 Oktober. SPR.600-1/3/1Jld.3(19).

SPR. (2019). E-mel kepada pengkaji. 19 Februari. 
Tunde, S. R., MohdAzizuddinMohdSanni\& Ummu Atiyah Ahmad Zakuan. (2016). Election administration and democratic sustainability in Nigeria. The Social Science, 11(1), 6141-6148.

UCA News. (1990). Election Watch raises government ire, garners public support. 27 April. Diperoleh daripada https://www.ucanews.com/story-archive/?post_name=/1990/04/27/ election-watch-raises-government-ire-garnerspublicsupport\&post_id=30411.

Ufen, A. (2013). The 2013 Malaysia elections: Business as usual or part of a protracted transition? Journal of Current Southeast Asian Affairs, 32(2), 3-17.

Virgianita, A. (2014). The role of civil society organisations in democratic transition: The case of international democracy assistance to domestic election monitoring organisations (DEMOs) in Indonesia (Tesis Doktor Falsafah). Diakses daripada Graduate School of International Studies, Meiji Gakuin University.

Walker, C. (2016). The hijacking of soft power. Journal of Democracy, 27(1), 49-63.

Wan Ahmad Wan Omar, Mantan Timbalan Pengerusi SPR, Putrajaya. (2018, 26 Disember). Temu bual.

Weiss, M.L. (2016). Payoffs, parties, or policies: Money politics and electoral authoritarian resilience. Critical Asian Studies, 48(1), 77-99.

Wong Chin Huat. (2018). Constituency delimitation and electoral authoritarianism in Malaysia. The Round Table, 107(1), 67-80.

Yap Swee Seng, Pengarah Eksekutif BERSIH, Petaling Jaya. (2019, 7 Januari). Temu bual.

Ying, Khoo Hooi. (2014). Human rights advocacy in Malaysia: The case of the Suara Rakyat Malaysia (SUARAM). Malaysian Journal of International Relations, 2, 130-150. 